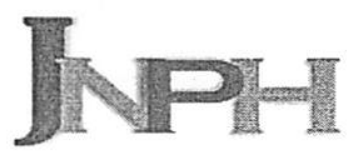

Volume 2 No. 2 (Desember 2014)

(C) The Author(s) 2014

\title{
Hubungan Pengetahuan Ibu tentang Demam Typhoid dengan Pemberian Nutrisi dan Cairan pada Klien Demam Typhoid Usia 1-6 Tahun di Ruang Edelwis RSUD DR M. Yunus Bengkulu 2014
}

\author{
The Relationship Between Mother's Knowledge about Typhoid Fever With To Give the Nu- \\ trition and Liquid to Typhoid Client ages 1-6 years in Edelwis Room In Dr.M.Yunus Hospi- \\ tal Bengkulu 2014
}

\author{
Ravika Ramlis ${ }^{2}$ \\ ravikaramlis999@gmail.com
}

\section{BSTRIK}

Penyakit demam typhoid yang biasa juga disebut typus atau types merupakan salah satu penyakit menular yang - disebabkan bakteri salmonela typhi yang menyerang saluran percernaan. Penyakit ini mudah ditemukan dan selalu ada dimasyarakat (endemik) Indonesia, mulai dari usia balita, anak-anak dan dewasa. Tujuan penelitian ini untuk mengetahui tingkat pengetahuan ibu tentang demam typhoid dengan pemberian nutrisi dan cairan pada klien demam typhoid usia 1-6 tahun di Ruang Edelweis RSUD M. Yunus Bengkulu.Tujuan penelitian ini adalah mengetahui hubungan pengetahuan ibu tentang demam typhoid dengan pemberian nutrisi dan cairan pada klien demam typhoid usia 1-6 tahun di ruang edelweis RSUD M.Yunus BengkuluTahun 2014.Metode penelitian yang di gunakan secara analitik dengan pendekatan cross sectional. Penelitian ini dilakukan di RSUD M. Yunus Bengkulu pada bulan Juni s.d Juli 2014. Populasi penelitian ini adalah seluruh ibu dengan anak usia 1-6 tahun yang menderita demam typhoid yang di rawat inap di RSUD M. Yunus Bengkulu dengan jumlah sampel sebanyak 40 orang dengan memberikan 10 kuesioner kepada ibu.Hasil penelitian ini menunjukkan dengan $\rho<0,05$ artinya ada hubungan antara pengetahuan ibu tentang demam typhoid dengan pemberian nutrisi dan cairan pada klien demam typhoid usia 1-6 tahun di Ruang Edelweis RSUD M. Yunus Bengkulu.Disarankan kepada responden yang di pilih mempunyai pengetahuan yang baik tentang demam typhoid, memberikan nutrisi dan cairan yang baik serta menjadi responden atas kemauan sendiri.

Kata Kunci : Pengetahuan, Pemberian Nutrisi dan Cairan

ABNIRSTI

Typhoid fever is also called typus or types is one disease that caused salmonella typhi bacteria that attack the digestive tract. The disease is easy to find and there is always Rustam (endemic) Indonesia, from the age of toddlers, children and adults. The purpose of this study to determine the knowledge level of the mother of typhoid fever by giving nutrition and fluids on the client typhoid fever at the age of 1-6 years Edelweis space RSUD M. Yunus Bengkulu. The purpose of this study was to find the relationship knowledge on typhoid fever by giving nutrition and fluids on the client typhoid fever at the age of 1-6 years separate Edelweis RSUD M.Yunus Bengkulu. The research methods used in cross-sectional analytical approach. The research was conducted in RSUD M. Yunus Bengkulu in June sd July 2014 population of this research is the mother of children aged 1-6 years who suffer from typhoid fever in hospitalized in RSUD M. Yunus Bengkulu with a total sample of 40 people with give 10 questionnaires to the mother. The results of this study show $\rho<0.05$ means that there is the relationship between parents' knowledge about typhoid fever by giving nutrition and fluids on the client typhoid fever at the age of 1-6 years Edelweis space RSUD M. Yunus Bengkulu. It is recommended to select respondents on a good knowledge of typhoid fever, which provide nutrition and fluids as well as a respondent on his own volition .

Keywords : Knowledge, Empowerment Nutrition and Fluid 


\section{Ravika Ramlis \\ Hubungan Pengetahuan Ibu tentang Demam Typhoid dengan Pemberian Nutrisi dan Cairan pada Klien Demam Typhoid Usia 1-6 Tahun di Ruang Edelwis RSUD DR M. Yunus Bengkulu 2014}

\section{PENDAHULUAN}

Penyakit demam typhoid yang biasa juga disebut typus atau types merupakan salah satu penyakit menular yang disebabkan bakteri salmonela enterica, khususnya turunan salmonela typhi terutama menyerang saluran percernaan. Penyakit ini mudah ditemukan dan selalu ada dimasyarakat (endemik) Indonesia, mulai dari usia balita, anak-anak dan dewasa (Djoko Widodo, 2006).

Didunia dari tahun 2005-2007 mencatat sekitar 42.564 orang menderita typhoid dan 214 meninggal dunia. Penyakit ini biasanya menyerang anak-anak pra-sekolah maupun usia sekolah akan tetapi tidak menutup kemungkinan juga menyerang orang dewasa. Badan kesehatan dunia (WHO) tahun 2008 memperkirakan jumlah kasus demam typhoid di seluruh dunia mencapai 16-33 juta dengan 500-600 ribu kematian tiap tahunnya (Suriadi \& Yuliani, 2001).

Berdasarkan dari data Rumah Sakit Dr.M.Yunus Bengkulu tahun 2010 diketahui bahwa angka kejadian demam typhoid sebesar 357 orang dengan 76 adalah pasien anak usia 1-6 tahun. Kasus demam typhoid pada tahun 2011 dengan angka kejadian sebesar 361 orang dengan 72 pada anak usia 1-6 tahun. Kasus demam typhoid pada tahun 2012 dengan angka kejadian berjumlah 992 orang dengan 163 pada anak usia 1-6 tahun. Sedangkan pada tahun 2013 dari bulan Januari-Juni didapatkan data kejadian demam typhoid berjumlah 322 orang dengan 66 pada anak usia 1-6 tahun (Profil RSUD Dr. M.Yunus Bengkulu 2010-2013).

Demam typhoid merupakan penyakit infeksi akut yang mengenai saluran percernaan dengan gejala demam lebih dari satu minggu, gangguan pada percernaan dan kesadaran. Demam typhoid lebih sering ditemukan pada anak-anak di bandingkan pada orang dewasa. Anak yang menderita demam typhoid perlu diberikan perawatan khusus karena kebanyakan anak yang dirawat dirumah sakit sering nafsu makannya sangat merosot, mengalami penurunan berat badan. Konsumsi makanan yang adekuat perlu di- jaga selalu pada anak sakit, karena kita tahu pada anak yang sakit tidak sanggup memasukkan makanannya sendiri dan anak tidak mau makan karena masalah hambatan psikis, anorexia, masalah saluran cerna, dan lain sebagainya (Ngastiyah, 2005).

Anak yang berat badannya menurun selama dirawat yang di akibatkan kurangnya masukan makanan selama sakit dapat mengganggu tumbuh kembangnya baik secara fisik, mental, sosial dan intelektual, karena pada masa ini pada anak masih terjadi proses pertumbuhan dan perkembangan yang memerlukan nutrisi dan cairan dalam jumlah yang besar sehingga peranan nutrisi dan cairan sangan penting dalam proses penyembuhan sakit anak (Santoso, 2005).

Hasil penelitian yang dilakukan di Kabupaten Purworejo sekitar $30 \%$ dari anak yang dirawat dirumah sakit mengalami penurunan berat badan. Konsumsi makanan yang adekuat perlu dijaga selalu pada anak sakit, karena kita tahu pada anak yang sakit sering nafsu makannya sangat merosot, tidak sanggup memasukkan makanannya sendiri dan anak tidak mau makan karena masalah hambatan psikis, anorexia, masalah saluran cerna dan lain sebagainya (Santoso, 2005).

Peran keluarga terutama ibu sangatlah dominan dalam merawat, mendidik dan mengasuh anak. Jika pengetahuan ibu baik biasanya ibu akan cenderung melakukan perawatan yang baik serta memahami tentang pemberian nutrisi dan cairan yang diberikan pada anaknya. Maka dituntut peran orang tua terutama ibu terhadap kesehatan anaknya yang salah satunya melalui pengetahuan (Santoso, 2005).

Berdasarkan pengamatan dan wawancara awal peneliti saat melakukan pra penelitian dengan beberapa ibu di Rumah Sakit Dr.M.Yunus Bengkulu diketahui sebagian ibu yang memiliki anak usia 1-6 tahun kurang mengerti mengenai penyakit demam typhoid. Pada waktu ditanyai mengenai penyakit tersebut tentang pengertian, penyebab, tanda dan gejala, pencegahan dan penularan, komplikasi, bagaimana ibu melakukan perawatan dan bagaimana pemberian nutrisi dan cairan selama anak sakit. Hasilnya sebagian besar ibu belum mengetahui jawaban dari pertanyaan yang diberikan. Hal ini lah yang mungkin menyebabkan masih tingginya angka kejadian demam typhoid pada anak usia 1-6 tahun di Rumah Sakit Dr.M. Yunus Bengkulu. 


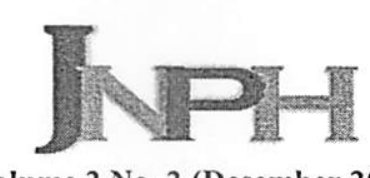

Volume 2 No. 2 (Desember 2014)

(C) The Author(s) 2014

untuk mengadakan penelitian tentang : "Hubungan Pengetahuan Ibu tentang Demam Typhoid dengan Pemberian Nutrisi dan Cairan pada Klien Demam Typhoid Usia 1-6 Tahun di Ruang Edelweis RSUD Dr. M.Yunus Bengkulu Tahun 2014".

\section{METODE}

Metode penelitian yang digunakan dalam penelitian ini adalah penelitian secara analitik dengan menggunakan desain crosssectional yang merupakan rencana penelitian suatu penelitian untuk mempelajari dinamika korelasi antara fakto-faktor resiko atau variabel independent (Pengetahuan ibu 'dalam pemberian nutrisi dan cairan) dengan efek atau variabel dependent (demam typhoid pada anak usia 1-6 tahun) yang diobservasi atau pengumpulan data sekaligus pada suatu saat yang sama (Notoatmojdo, 2010).Metode penelitian yang di gunakan secara analitik dengan pendekatan cross sectional. Penelitian ini dilakukan di RSUD M. Yunus Bengkulu pada bulan Juni s.d Juli 2014. Populasi penelitian ini adalah seluruh ibu dengan anak usia 1-6 tahun yang menderita demam typhoid yang di rawat inap di RSUD M. Yunus Bengkulu dengan jumlah sampel sebanyak 40 orang dengan memberikan 10 kuesioner kepada ibu.

Peneliti mengambil surat rekomendasi dari STIKes Dehasen Bengkulu Prodi Keperawatan, setelah mendapat surat izin dari STIKes Dehasen Bengkulu, peneliti melanjutkan permohonan izin ke KP2T yang diteruskan ke RSUD M. Yunus Bengkulu. Peneliti mendapat surat rekomendasi penelitian kemudian penelitian di laksanakan dari tanggal 23 Juni sampai 3 Juli 2014.Populasi dari penelitian ini adalah seluruh anak usia 1-6 tahun di Ruang Edelweis RSUD M. Yunus Bengkulu dengan jumlah sampel 40 anak. Hasil penelitian di sajikan dalam tabel dan narasi baik analis univariat dan bivariat dari setiap demam typhoid, memberikan nutrisi dan cairan yang baik serta menjadi responden atas kemauan sendiri berdasarkan tabel dibawah tersebut :

Tabel 1. Distribusi Frekuensi Responden

\begin{tabular}{|lcc|}
\hline Pengetahuan & Frckucnsi & Presentase \\
\hline Kurang & 17 & 42,5 \\
Baik & 23 & 57,5 \\
\hline Jumlah & 40 & 100 \\
\hline
\end{tabular}

Berdasarkan Pengetahuan

Berdasarkan tabel 1 diatas menunjukkkan bahwa sebagian besar dari responden $(57,5 \%)$ berpengetahuan baik tentang demam typhoid.

Tabel 2. Distribusi Frekuensi Tentang

\begin{tabular}{|lcc|}
\hline Pemberian Nutrisi dan Cairan & Frekucnsi & Presentasc \\
\hline Kurang Baik & 16 & 40 \\
Baik & 24 & 60 \\
& & \\
\hline Jumlah & 40 & 100 \\
\hline
\end{tabular}

Pemberian Nutrisi dan Cairan

Berdasarkan tabel 2 diatas menunjukkkan bahwa sebagian besar dari responden $(60 \%)$ melakukan pemberian nutrisi dan cairan dengan baik.

Tabel 3. Hubungan Pengetahuan Ibu dengan Pemberian Nutrisi dan Cairan 
Ravika Ramlis

Hubungan Pengetahuan Ibu tentang Demam Typhoid dengan Pemberian Nutrisi dan Cairan pada Klien Demam Typhoid Usia 1-6 Tahun di Ruang Edelwis RSUD DR M. Yunus Bengkulu 2014

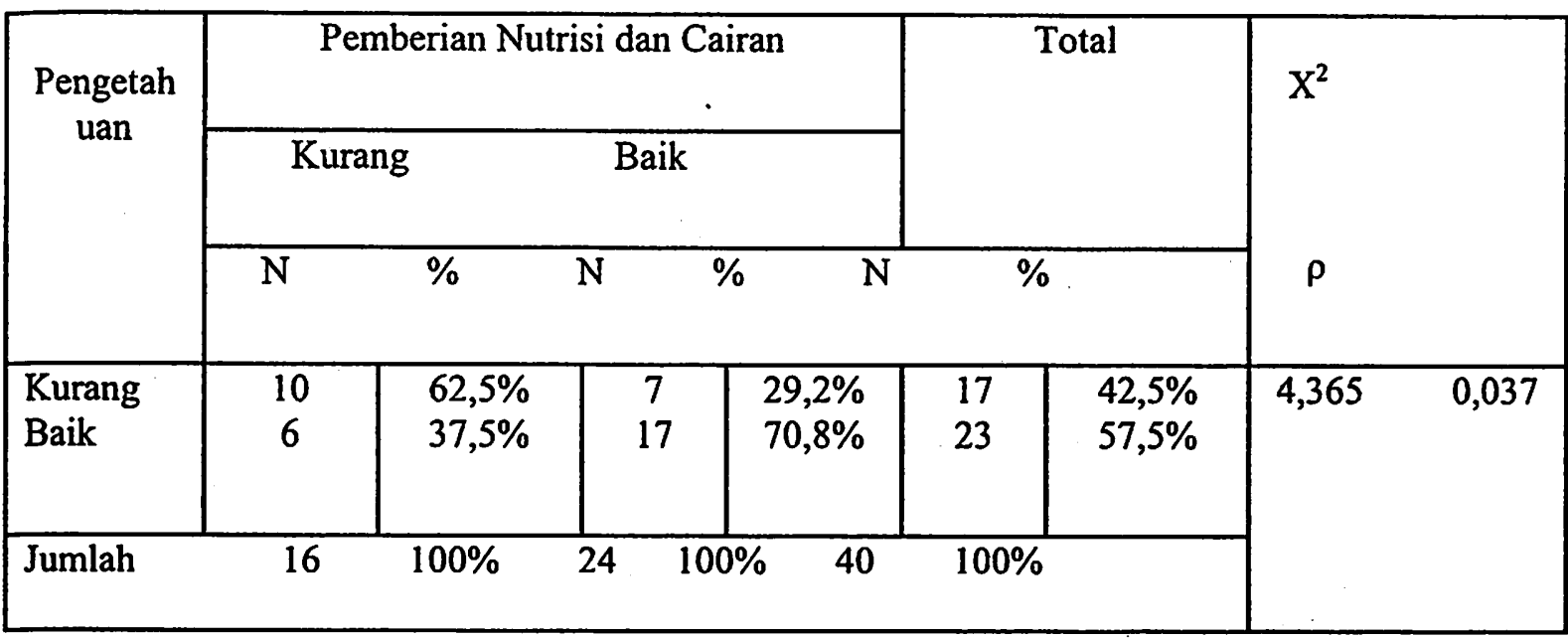

Berdasarkan tabel 3 diatas menunjukkan bahwa responden yang pengetahuan kurang melakukan pemberian nutrisi dan cairan yang kurang baik yakni $62,5 \%$ dan melakukan perawatan yang baik $29,2 \%$. Kemudian responden yang pengetahuan baik melakukan pemberian nutrisi dan cairan yang kurang baik yakni $37,5 \%$ dan melakukan perawatan yang baik $70,8 \%$ serta hasil analisis Chi-Square di peroleh nilai $\mathrm{X}^{2 *} 4,365$ dengan nilai $\rho=0,037$.

\section{DISKUSI}

Pengetahuan adalah sesuatu yang diketahui atau kepandaian yang dimiliki seseorang melalui pendidikan atau pengalaman serta hasil tahu yang terjadi setelah orang melakukan penginderaan terhadap suatu objek tertentu. Penginderaan terjadi melalui panca indera manusia yakni indera penglihatan, pendengaran, penciuman, perasa dan peraba. Sebagian besar pengetahuan manusia diperoleh melalui mata dan telinga (Notoatmodjo, 2007).

Pengukuran pengetahuan dapat dilakukan dengan wawancara atau angket yang menanyakan tentang isi materi yang ingin diukur dari subjek penelitian atau responden. Kedalaman pengetahuan yang ingin diketahui atau diukur dapat disesuaikan dengan tingkat-tingkat domain kognitif. Menurut tingkatnya terdiri dari enam tingkatan antara lain : tahu, memahami, aplikasi, analisis, sintetis serta evaluasi (Notoadmodjo, 2010).

Hasil penelitian yang di lakukan penulis di Ruang Edelweis RSUD M. Yunus
Edelweis RSUD M. Yunus Bengkulu dari sampel 40 responden yang di teliti di dapatkan ibu yang berpengetahuan kurang berjumlah 17 orang dengan persentase $42,5 \%$ dan berpengetahuan baik berjumlah 23 orang dengan persentase $57,5 \%$.

Kriteria dari responden penelitian di dapatkan berpendidikan S1 (Sarjana 7 orang), D3 (Diploma 5 orang), SMA (Sekolah Menengah Atas 9 orang), SMP (Sekolah Menengah Pertama 6 orang ), SD (Sekolah Dasar 9 orang) serta tidak sekolah berjumlah 4 orang. Berdasarkan dari segi usia terdapat 10 orang di atas usia 30 tahun, 16 orang 26-30 tahun, 11 orang 20-25 tahun, 3 orang dibawah 20 tahun serta dari segi pekerjaan sebagian besar adalah sebagai IRT (Ibu Rumah Tangga).

Hasil penelitian yang di lakukan di Kabupaten Purworejo tahun 2010, menunjukkan bahwa sebagian besar responden berpendidikan tinggi dengan usia di atas usia $\mathbf{3 0}$ tahun dengan persentase $60 \%$ berpengetahuan baik dan $40 \%$ berpengetahuan kurang (Kasdu, 2009).

Jadi, semakin tinggi pendidikan dan banyaknya pengalaman seseorang semakin semakin tinggi juga tingkat pengetahuannya. Hasil penelitian tersebut penulis sesuai dengan hasil penelitian Kasdu, maka dapat simpulkan bahwa pengetahuan seseorang sangat di pengaruhi oleh pendidikan dan pengalaman.

1. Pemberian Nutrisi dan Cairan

Dari sampel 40 responden yang di teliti di dapatkan ibu yang memberikan nutrisi dan cairan yang kurang baik berjumlah 16 orang dengan persentase $40 \%$ dan yang memberikan nutrisi 


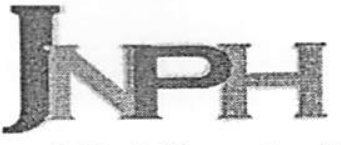

Volume 2 No. 2 (Desember 2014)

(C) The Author(s) 2014

Hasil penelitian yang dilakukan penelitian lain menyatakan bahwa $30 \%$ anak yang di rawat di rumah sakit mengalami penurunan berat badan. Penurunan berat badan anak dapat di sebabkan dari kondisi sakit anak dan tidak adekuatnya pemberian nutrisi dan cairan pada anak selama di rawat di rumah sakit (Santosa, 2006).

Jika pemberian nutrisi dan cairan kurang baik pada anak demam typhoid maka anak akan rentang terhadap penurunan berat badan selama di rawat di rumah sakit dan sebaliknya jika pemberian nutrisi dan cairan baik maka kebutuhan nutrisi pada anak akan adekuat dan berat badan dapat di pertahankan selama di rawat di rumah sakit. Jadi tujuan memberikan pemberian nutrisi dan cairan pada anak sakit adalah untuk menjaga agar anak tetap mengkonsumsi makanan dan cairan dengan baik selama di rawat.

2. Hubungan Pengetahuan dengan Pemberian Nutrisi dan Cairan

Peran keluarga terutama ibu sangatlah dominan dalam merawat, mendidikdan mengasuh anak, jika pengetahuan ibu baik biasanya ibu cenderung melakukan perawatan yang baik pula terutama dalam pemberian nutrisi dan caiarn, maka di tuntun peran keluarga terutama ibu terhadap kesehatan anaknya yang salah satunya melalui pengetahuan (Santoso, 2006).

Pemberian nutrisi dan cairan pada anak sakit terutama yang di rawat di rumah sakit adalah untuk menjaga agar anak tetap mengkonsumsi makanan dengan baik. Sebagaiman diketahui anak yang sakit akan mengalami peningkatan metabolisme maupun katabolisme, ini berarti terjadi gangguan nutrisi dan cairan yang dimulai semenjak anak mulai terganggu kesehatannya.

Dari sampel 40 responden yang di teliti di dapatkan hasil yang pengetahuan kurang melakukan pemberian nutrisi dan cairan yang kurang baik yakni $62,5 \%$ dan melakukan perawatan yang baik 29,2 \%. Kemudian responden yang pengetahuan baik melakukan pemberian nutrisi dan cairan yang kurang baik yakni $37,5 \%$ dan melakukan perawatan yang baik $70,8 \%$.

Hasil analisis Chi-Square di peroleh nilai $\mathrm{X}^{2}$ $=4,365$ dengan nilai $\rho=0,037$, hal ini dapat di simpulkan bahwa $\mathrm{Ha}$ di terima, artinya ada hubungan antara pengetahuan ibu tentang dengan pemberian nutrisi dan cairan pada pasien demam typhoid usia 1-6 tahun di Ruang Edelweis RSUD M. Yunus Bengkulu tahun 2014.

Jadi, jika pengetahuan ibu baik maka ibu akan memberikan nutrisi dan cairan yang baik pula sebaliknya jika pengetahuan ibu kurang ibu akan memberikan pemberian nutrisi dan cairan yang kurang baik pula.

\section{KESIMPULAN}

Berdasarkan hasil penelitian tentang hubungan pengetahuan ibu tentang demam typhoid dengan pemberian nutrisi dan cairan pada klien demam typhoid usia 1-6 tahun di Ruang Edelweis RSUD M. Yunus Bengkulu tahun 2014, maka dapat di simpulkan sebagai berikut :

1. Sebagian besar responden memiliki pengetahuan yang baik.

2. Sebagian besar responden memberikan nutrisi dan cairan dengan baik.

3. Ada hubungan pengetahuan ibu dengan pemberian nutrisi dan cairan pada klien demam typhoid usia 1-6 tahun di RSUD Dr.M. Yunus Bengkulu Tahun 2014.

\section{SARAN}

\section{Bagi Pihak Rumah Sakit}

Hasil penelitian ini dapat memberikan informasi kepada pihak rumah sakit tentang kejadian demam typhoid pada klien usia 1-6 tahun dan diharapkan hasil penelitian ini dapat menjadi masukan dalam meningkatkan mutu pelayanan keperawatan terutama dalam penanganan, pencegahan, promosi kesehatan kepada masyarakat serta pemberian nutrisi dan cairan pada pasien demam typhoid.

\section{Bagi STIKes Dehasen Bengkulu}

Hasil penelitian ini diharapkan dapat dijadikan bahan informasi sumber pustaka bagi mahasiswa dalam menyusun penelitian serupa dimasa mendatang dan diharapkan penelitian ini dapat dijadikan sebagai sumber acuan pembelajaran pada pihak institisi pendidikan.

Bagi Peneliti Lain

Hasil penelitian ini diharapkan dapat digunakan sebagai data dasar untuk penelitian serupa 


\section{Ravika Ramlis}

Hubungan Pengetahuan Ibu tentang Demam Typhoid dengan Pemberian Nutrisi dan Cairan pada Klien Demam Typhoid Usia 1-6 Tahun di Ruang Edelwis RSUD DR M. Yunus Bengkulu 2014

serupa yang berhubungan dengan kejadian demam typhoid dan diharapkan penelitian ini akan memberikan informasi dan masukan pada peneliti yang akan datang dalam membuat bentuk penelitian yang lain atau dikembangkan lebih lanjut.

4. Bagi Responden.

Hasil penelitian ini dapat dijadikan sebagai masukan bagi responden terutama ibu dalam meningkatkan derajat kesehatan anaknya dengan demam typhoid dan khususnya dalam pemberian nutrisi dan cairan yang adekuat. Bila pengetahuan ibu meningkat maka pemahaman ibu tentang pentingnya pemberian nutrisi dan cairan juga akan meningkaat sehingga kebutuhan nutrisi dan cairan anak terpenuhi dan anak menjadi cepat sembuh dan sehat kembali seperi biasanya.

\section{DAFTAR PUSTAKA}

Amin. 2013. Aplikasi Asuhan Keperawatan Berdasarkan Diagnosa Medis dan NANDA. Yogyakarta : Media Action Publishing.

Arikunto, S. 2006. Prosedur Penelitian: Suatu Pendekatan Praktek. Edisi Revisi VI. Jakarta: Rineka Cipta.

Asmadi. 2008. Konsep dan Aplikasi Kebutuhan Dasar Klien. Jakarta : Salemba Medika.

Aziz Alimul H.A. 2005. Pengantar Ilmu Keperawatan Anak 2. Jakarta : Salemba.

Brunner dan Suddarth. 2001. Buku Ajar Keperawatan Medikal Bedah. Edisi 8. Jakarta.

Djoko,Widodo. 2006. Buku Ajar Ilmu Penyakit Dalam. Jilid III. Edisi IV. Jakarta: FKUI.

Hidayat, A. 2009. Pengantar Kebutuhan Dasar Manusia. Buku 2. Jakarta : Salemba Medika.

Kozier, Barbara, dkk. 2010. Buku Ajar Fundamental Keperawatan. Edisi 7. Volumel. Jakarta: EGC

Ngastiyah. 2005. Perawatan Anak Sakit. Edisi 2. Jakarta : EGC.

Notoatmodjo, Soekidjo. 2010. Metodologi Penelitian Kesehatan. Jakarta: P.T Rineka Cipta.

Rampengan. 2008. Penyakit Infeksi Tropik Pada Anak. Edisi 2. Jakarta: EGC.

Santoso. 2005. Metodologi Penelitian Kuantitatf dan Kualitatif. Jakarta: Prestasi Pustaka.

Syaifudin, AMK. 2006. Anatomi Fisiologi
Untuk Mahasiswa Keperawatan. Edisi 3. Jakarta : EGC.

Sulıardjo. 2006. Pangan, Gizi, Pertanian. Jakarta: Universitas Indonesia.

Suriadi dan Yulaini. 2001. Asuhan Keperawatan Pada Anak. Edisi 1. Jakarta: Fajar Intan Pratama.

Tarwoto \& Wartonah. 2010. Kebutuhan Dasar Manusia dan Proses Keperawatan. Edisi 4. Jakarta : Salemba Medika. 